7-31-2019

\title{
Assessing a community-based waste separation program through examination of correlations between participation, information exposure, environmental knowledge, and environmental attitude
}

\author{
Vita Ruliana \\ School of Environmental Science, Universitas Indonesia, vitaruliana@gmail.com \\ Roekmijati W. Soemantojo \\ Faculty of Engineering, Universitas Indonesia
}

See next page for additional authors

Follow this and additional works at: https://scholarhub.ui.ac.id/ajce

Part of the Social and Behavioral Sciences Commons

\section{Recommended Citation}

Ruliana, Vita; Soemantojo, Roekmijati W.; and Asteria, Donna (2019). Assessing a community-based waste separation program through examination of correlations between participation, information exposure, environmental knowledge, and environmental attitude. ASEAN Journal of Community Engagement, 3(1).

Available at: https://doi.org/10.7454/ajce.v3i1.120

Creative Commons License

\section{(c) (i) (?)}

This work is licensed under a Creative Commons Attribution-Share Alike 4.0 License.

This Research Article is brought to you for free and open access by the Universitas Indonesia at ASEAN Journal of Community Engagement. It has been accepted for inclusion in ASEAN Journal of Community Engagement. 


\title{
Assessing a community-based waste separation program through examination of correlations between participation, information
} exposure, environmental knowledge, and environmental attitude

\author{
Vita Ruliana ${ }^{a^{*}}$, Roekmijati W. Soemantojo ${ }^{b}$, Donna Asteriac \\ ${ }^{a}$ School of Environmental Science, Universitas Indonesia \\ ${ }^{b}$ Faculty of Engineering, Universitas Indonesia \\ ${ }^{c}$ Faculty of Social and Political Science, Universitas Indonesia

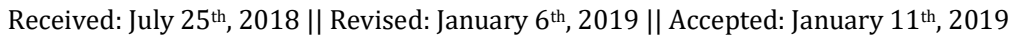

\begin{abstract}
Municipal solid waste has become one of major environmental issues and pollution sources. In cities of developing countries, the amount of waste is inversely proportional to the land area available for landfills. Cipayung Landfill in the city of Depok, Jakarta's southern border, cannot support the volume of waste generated by the city's 11 districts. This study presents the case of a community group in Tugu Village, Cimanggis, Depok, where a waste separation program had been adopted since 2014 but low rates of participation are still recorded. Earlier observations reveal uneven distribution and location of communal organic bins and transportation of mixed waste. Earlier researches discussed over relationship between waste management and people participation, information dissemination, environmental knowledge, attitude, behavior, facility availability, partially. Thus, this study aims to integrate all these notions by examining the correlations between participation, information exposure, environmental knowledge, environmental attitude and other conditions that may promote participation in waste separation practices. Quantitative approach with quantitative and qualitative methods is implemented. Questionnaires, interviews, and observations are used to collect data. Spearman correlations reveal that participation is very strongly correlated with information exposure, and environmental knowledge, but weakly correlated with environmental attitude. Other conditions include respondents' daily activities, residence period in the community, family welfare level, facilities provision, and role of community leaders. This study confirms the importance of information dissemination on a routine basis, valid and persuasive messages, facilities provision, and leading actor's role at the community level to help increase public participation in waste separation.
\end{abstract}

Keywords: household waste separation; sustainable solid waste management; community-based solid waste management

\section{Introduction}

Untreated solid waste causes environmental pollution. Unmanaged piles of solid waste in landfills release methane, a greenhouse gas that contributes to climate change. Leachates accumulated at the bottom of a landfill can contaminate the groundwater and pollute nearby water bodies. Health issues arise from the open dumping of mixed 
Vita Ruliana, Roekmijati W. Soemantojo, Donna Asteria | ASEAN Journal of Community Engagement | Vol. 3, No. 1, 2019

wastes, which creates an environment in which disease vectors, such as rats and flies, can breed. Scattered piles of mixed waste also lend an unpleasant aesthetic to the surroundings. Considering these facts, a proper waste management must, therefore, be given serious consideration in a city, especially when waste generation is constantly increasing in contrast to the availability of land area for disposal. In the typical traditional municipal solid waste practice, the collected waste is directly dumped into landfills without treatment, such as waste separation, reduce-reuse-recycle (the 3Rs), composting, and waste-to-energy conversion (Permana et al., 2015); unfortunately, this practice results in overloaded disposal sites. The same case can be observed in many cities in developing countries. In the city of Depok, a suburban town located at the southern border of the capital city of Indonesia, for example, the city's landfill, Cipayung Landfill, can no longer support all the waste generated by the city's 11 districts.

About 1,200 tons of waste was generated daily in Depok over the period 2014-2019. However, the landfill can only receive a maximum of 701.98 tons of waste per day, which means the remaining 580.85 tons of waste generated daily must be reduced somehow to avoid overloading the landfill, extend the landfill's lifespan, and prevent the creation of illegal disposal sites (Office of Sanitation and Environment Depok City, 2015). Several concerns over the nature of landfills have been raised. Previous researches reveal some problems arising from landfill activity in Cipayung. First, is leaked leachate that is not absorbed well into leachate stabilization pond which further contaminates shallow groundwater around the landfill, as confirmed by the pollution index of residents' well water within 300 meters radius from the leachate stabilization pond (Widiastuti et al., 2018). According to the study, the pollution index was between lightly and moderately contaminated. Second, contamination of Pesanggrahan River which is located in the lower ground level of the dumping site (Erlinna, 2012). Another issue was the prevalence of health problems, such as diarrhea, typhoid, skin infections, and respiratory infections, among residents living on the periphery of the dump site (Handono, 2010).

The environment encompasses three components: the natural environment, the artificial (human-built) environment, and the social environment. Friction between these three components can cause environmental problems (Soerjani, 2009). Environmental problems arise, for instance, when improperly managed solid waste is amassed to pollute the soil, ground water, and water bodies and release greenhouse gas. 
Vita Ruliana, Roekmijati W. Soemantojo, Donna Asteria | ASEAN Journal of Community Engagement | Vol. 3, No. 1, 2019

To manage the municipal solid waste, the local government issued Regulation of the City of Depok No. 5/2014, which suggested waste reduction at the source through waste separation practices, the 3Rs, and composting. Community involvement is essential because approximately $80 \%$ of the total municipal waste is generated by households (Regional Planning Agency Depok City, 2008). Thus, each household has an important role in reducing the quantity of waste buried in landfills. Waste is classified according to its material: recyclable, biodegradable, or residual. Recyclable waste is transported to waste banks, biodegradable waste is transported to composting unit, and residual waste is transported to landfills. Public participation in waste separation programs is a form of behavior based on ecocentrism, which emphasizes that humans are not only members of the social community but also members of the ecological community because, in fact, humans cannot live without other living beings and abiotic objects (Keraf, 2006).

Integration of waste separation at the source, composting, and recycling will help reduce municipal solid waste, promote environmental sustainability, reduce the need for final disposal sites, and, ultimately, prevent environmental pollution (Aquino et al., 2008). Sustainable solid waste separation involves not only control of waste storage, collection, transportation, and disposal but also engagement through proactive preventive strategies, such as the 3Rs and the use of eco-friendly waste-disposal technology (Siebel et al., 2013). Reducing waste volume must include separation of waste according to its main components to enhance recycling activity (Permana et al., 2015). Waste separation at the source and recycling are expected to reduce the amount of waste transported for final disposal and remove nonbiodegradable fragments from the biodegradable bulk, there by improve the quality and composition of waste for recycling and composting (Aquino et al., 2008).

\subsection{Comparison of Waste Management Hierarchy}

Waste separation is also in line with new waste management paradigm. Figure 1 compares the traditional and new paradigm of waste management. In the traditional paradigm, prevention, minimization, and waste recycling efforts are not carried out extensively; instead, the approach relies heavily on landfilling. Placing the burden of waste management on landfills leads to high operating and maintenance costs. Costs to overcome various environmental problems that may develop around the landfill area must also be considered. The new paradigm of waste management is also regarded as a 
4

Vita Ruliana, Roekmijati W. Soemantojo, Donna Asteria | ASEAN Journal of Community Engagement | Vol. 3, No. 1, 2019

more sustainable approach. Waste prevention is regarded as the preferred option; it prevents the production of waste or reduces the amount generated. The next step is reuse, recycle, composting, transformation waste to energy, and last is disposal. Disposal is the least favored option (Fagariba \& Song, 2017).

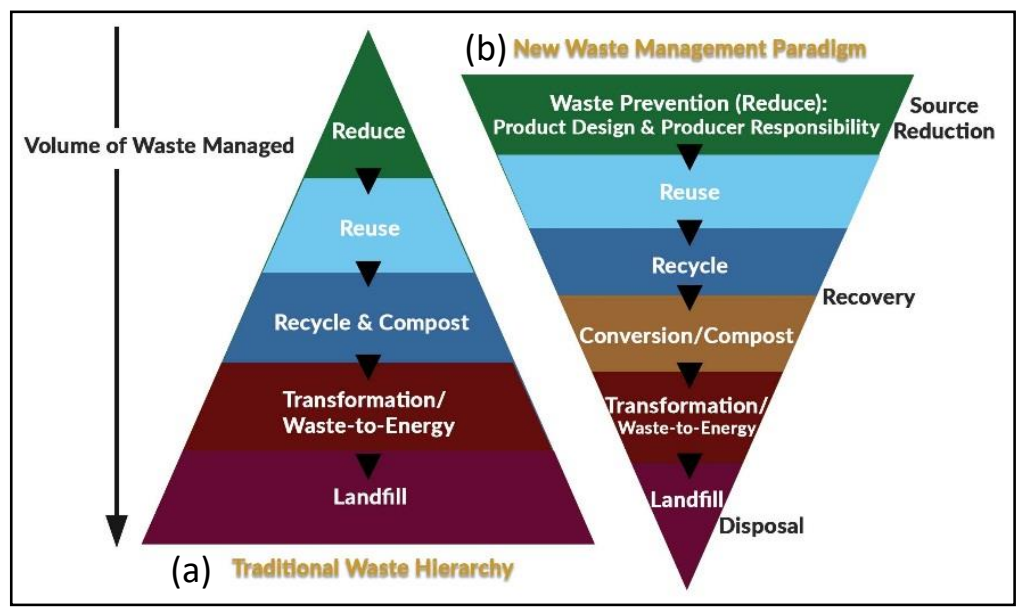

Fg. 1 Comparison of Waste Management Hierarchy

(a) Traditional Paradigm and (b) New Paradigm

Source: (Fagariba \& Song, 2017)

The aim of the sustainable approach is to generate the minimum amount of waste possible, thereby minimizing the amount of waste that must be disposed in landfills. The approach provides several side benefits as it prevents emissions of greenhouse gases, reduces pollutants, saves energy, saves costs, and conserves resources. The lower the waste volume in the landfill, the lower the management cost. In this hierarchy, waste separation at source is part of prevention step of the sustainable approach. Source separation is fundamental to integrated waste management. Separation allows the waste stream to be managed, preventing mixed waste so that cross-contamination is prevented. It allows valuable materials to be extracted, and more importantly enables downstream processing to be more efficient and the risks to the environment and public health to be reduced. Once mixed waste occurs the effort to separate out components is generally more costly (United Nations Environment Program, 2016).

A total of 125 residential areas apply waste separation programs in Depok City (Office of Sanitation and Environment Depok City, 2015), one of them is community group (it is later called RW 16), in Tugu Village, Cimanggis, which became the research 
Vita Ruliana, Roekmijati W. Soemantojo, Donna Asteria | ASEAN Journal of Community Engagement | Vol. 3, No. 1, 2019

locus. The socialization activities conducted include (1) dissemination of information regarding waste separation programs at the neighborhood administrative unit (hereinafter referred to as RT) and community group levels, (2) distribution of leaflets containing procedures for household waste separation to each household, (3) establishment and introduction of Waste Bank Bukit Cengkeh and its activities, (4) distribution of organic waste communal bins in all neighborhoods, and (5) distribution of small organic waste buckets to each household. The importance of community involvement is stressed by (Ogawa, 1996), who found that, in a developing country, initiation of a program is sometimes hindered by unskilled human resources in the government sector. This problem is likely to occur when the issue being addressed is given low priority in a development program. Thus, mobilizing human resources at the community level may be necessary. Involving people in an activity also means building community self-reliance.

Community waste separation was introduced to Depok City in 2014, but participation in this program remains low and is shown by several observations: communal bins to place organic waste are not distributed and located and transportation of mixed waste still occurs. The low participation recorded is assumed to be due to differences in the level of acceptance of information about waste separation, environmental knowledge, and environmental attitudes among residents. Other conditions may also influence community participation. Previous researchers have revealed the factors encouraging people to manage their waste in an environmentally friendly manner, including dissemination of information on waste segregation programs (Von Borgstede \& Andersson, 2010; Arbi, 2015), environmental knowledge and attitude (Kaiser et al., 1999; 0’Brien, 2007; Von Borgstede \& Andersson, 2010; Wright, 2011; Desa et al., 2012), and the integration between awareness, knowledge, skills, and a positive attitude toward the environment to achieve a good quality of environment in general (Asteria, 2012).

Emphasizes the importance of information dissemination to campaigns for waste separation (Arbi, 2015). Along with technological innovations, disseminating information on recycling programs to the public is essential to raise awareness and increase public participation (Von Borgstede \& Andersson, 2010). Implementation of waste recycling programs must be accompanied by enough information on how and where people can participate. For the information to be accepted and well perceived, 
Vita Ruliana, Roekmijati W. Soemantojo, Donna Asteria | ASEAN Journal of Community Engagement | Vol. 3, No. 1, 2019

socialization must be done intensely and continuously (Ruben \& Stewart, 1998; Wibowo, 2010). The activist engaged in socialization must also provide valid and persuasive arguments on the importance of the issues at hand. Examples of possible arguments include disclosure of the city waste volume, the condition of landfills, and threats to the environment and health (Young, 1988). Environmental knowledge and attitudes are significant prerequisites for an individual to adopt ecologically friendly behavior (Kaiser et al., 1999). Being knowledgeable helps an individual build and shape their attitude (O'Brien, 2007). However, the level of environment knowledge is also influenced by one's educational background (Sudarmadi et al., 2001; Mancl, Carr, \& Morrone, 2003), as well as the level of family welfare (Mancl et al., 2003; Notoatmodjo, 2003). The involvement of environmental attitude in this research originates from the assumption that an individual's behavior is associated with their attitude (Desa et al., 2012). Researchers have expressed various points of view on the relationship between behavior and attitude. Some researchers argue that attitude is a factor determining an individual's behavior (Von Borgstede \& Andersson, 2010), while others disagree. In fact, inconsistencies between behavior and attitude are often found (Wright, 2011; Desa et al., 2012), especially when situational influences affect the relationship between attitude and behavior (Kaiser et al., 1999). Situational influences can be generated by several factors, such as habit, discomfort, lack of law enforcement, and lack of awareness on one's role and responsibility in protecting the environment (Desa et al., 2012).

Participation means one's involvement in an activity. Involvement can be formed by social interactions between individuals and their community. Social interaction creates opportunities to exchange information, discuss activities in the community, and motivate others, eventually creating awareness and interest to participate among individuals within the community (Setiana, 2005). Participation also relates to the intrinsic and extrinsic characteristics of an innovation. Intrinsic characteristics are attached to the innovation itself, which can be explained as the distinction and complexity of the innovation. Extrinsic characteristics describe the suitability of the innovation for the local environment and the advantage of the innovation compared with the existing technology (Setiana, 2005). According to Aquino, et al. (2008), one of the factors determining the success of a waste separation program at the household level is the location of waste banks; when these banks are accessible to residents and located close to residential areas, they are likely to be used often. This study integrates 
Vita Ruliana, Roekmijati W. Soemantojo, Donna Asteria | ASEAN Journal of Community Engagement | Vol. 3, No. 1, 2019

all the above-mentioned notions about sustainable waste management, community involvement, information dissemination, environmental knowledge and attitude, the nature of innovation, and to also try to look for other factors that may also contribute to participation in waste separation.

This research aims to evaluate the implementation of waste separation programs by analyzing the relationships between level of participation, level of information exposure, level of environmental knowledge, and attitude toward the environment, as well as other conditions that may help influence participation. The specific research objectives are to (1) identify the participation level of communities in waste separation programs, level of information exposure acceptance, level of environmental knowledge, and attitude toward the environment; (2) analyze the relationships between level of participation, level of information exposure acceptance, level of environmental knowledge, and attitude toward the environment; and (3) analyze conditions that may contribute to community participation in waste separation programs.

\section{Methods}

This research employed the quantitative approach with quantitative and qualitative methods. The quantitative method was employed to acquire primary information on the level of participation, information exposure acceptance, environmental knowledge, and attitude toward the environment through a questionnaire distributed to target respondents. The qualitative method was employed to obtain information on the development of waste separation practices and socialization activities. This portion of the research was carried out through interviews and observation. This research was conducted at RW 16, Village of Tugu, subdistrict of Cimanggis, city of Depok, from August 2016 to December 2017.

The respondents targeted to acquire information on community-level participation, information exposure acceptance, environmental knowledge, and attitude toward the environment were all heads of households living in RW 16 at the time of the survey. Samples were determined using the two-stage cluster method. RW 16 consists of 13 RTs. The first step in sample selection was to decide which RTs are to be cluster samples; RT 01, RT 02, RT 05, RT 06, and RT 13 were eventually selected. The total population of these five RTs was 274 heads of households. The sample size was 
Vita Ruliana, Roekmijati W. Soemantojo, Donna Asteria | ASEAN Journal of Community Engagement | Vol. 3, No. 1, 2019

determined by the Slovin formula with a $10 \%$ degree of fault from the population with another $10 \%$ to avoid errors in filling out the questionnaires. Hence, the required sample size was 80 heads of households. The second step in the sample selection process was to decide the number of heads of households to serve as the sample in each RT; this number was determined as a proportion of the total population of household heads in that RT.

The questionnaire consisted of questions related to the respondent's identity, frequency of sorting waste in a week, intensity to receive information, knowledge of how to sort waste, environmental knowledge, and attitude toward the environment. This questionnaire was pre-tested on 30 people in RW 16 outside the target sample. Fourteen questions in intensity to receive information were considered valid according to their Pearson product moment coefficient correlation scores $(>0.3$, the critical value for correlation coefficients in the two-sided test at a significance of 0.05 with $n=30$ ). Twelve questions on knowledge of how to sort waste, 24 questions on environmental knowledge, and 19 questions on attitude toward the environment were found to be valid under the same measure. Reliability was determined using Cronbach's alpha. Overall, the alpha score of 19 questions in intensity to receive information was 0.927 , that of 12 questions on knowledge of how to sort waste was 0.937 , that of 24 questions on environment knowledge was 0.959 , and that of 19 questions on attitude toward the environment was 0.984 .

Interviews were first conducted during a pre-survey on administrators to determine the waste management model in RW 16 and the socialization activities that had been carried out. Several individuals who were eligible to become sources of other information were then obtained; this group included heads of RTs, the founder of the waste bank, the operating manager of the waste composting unit in Gunadarma (UPS Gunadarma), and some environment activists. Samples were determined using purposive and snowball sampling. Each interview was conducted individually and faceto-face. Interviews were conducted by using an interview guide, but the order and form of questions were flexibly adjusted. Observations were carried out to determine the existence of waste separation facilities, such as communal organic-waste bins in each RT and the waste bank. To do so, the researchers joined UPS Gunadarma officers while collecting organic waste from each communal bin in RW 16. 
Vita Ruliana, Roekmijati W. Soemantojo, Donna Asteria | ASEAN Journal of Community Engagement | Vol. 3, No. 1, 2019

To ensure the validity of the data, observations and interviews were conducted in 2016, and a field survey was carried out in 2018. The researchers triangulated data sources by collecting data not only from the residents of cluster samples but also from the informants, as mentioned above. The researchers also triangulated the data collection technique. Respondents' answers to the questionnaire were compared with the information provided by the informants, and information from interviews was cross-checked among informants. Answers among respondents were compared; answers that were similar or identical were grouped in order to identify the common issue revealed from the respondents. Finally, all data collected from the questionnaires and interviews were confirmed by findings from the observations and data provided by the UPS Gunadarma office.

\subsection{Conceptual Framework}

This research consists of three variables $\mathrm{X}$, including level of information exposure acceptance, level of environment knowledge, and attitude toward the environment, and one variable $Y$, representing level of participation in waste separation. The relationship between variables is shown by the conceptual framework

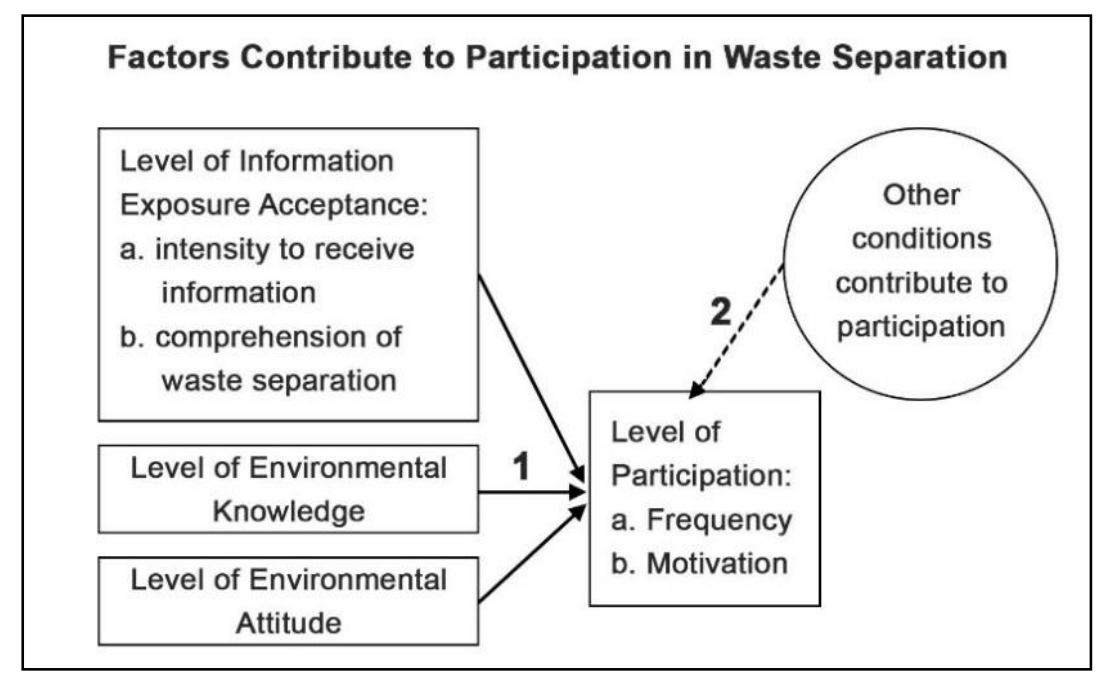

Fg. 2 Conceptual Framework

Based on this framework, the hypotheses to be attested partially are: (1) correlations exist between level of participation in waste separation and level of information exposure acceptance, level of environmental knowledge, and attitude toward the 
10

Vita Ruliana, Roekmijati W. Soemantojo, Donna Asteria | ASEAN Journal of Community Engagement | Vol. 3, No. 1, 2019

environment; and (2) other conditions may contribute to community participation in waste separation programs.

Participation level was measured by probing the frequency with which the residents sorted their waste in a week. Information exposure acceptance was measured by questioning how often the residents received information about waste separation practices in a year and how well they understood the waste separation procedure, objectives, and advantages. Environmental knowledge level was measured by assessing the respondents' knowledge of basic concepts of ecology and global and local environmental issues. To measure respondents' environmental attitude, statement sentences related to environment protection efforts and eco-friendly practices were provided; answers to these questions ranged from "totally disagree" to "totally agree." Measurements were conducted by using a Likert-scale questionnaire. The socioeconomic profile of respondents was also acquired to understand other conditions that may contribute to community participation in waste separation programs.

\subsection{Spearman Correlation Coefficients}

Each answer was given a score from lowest to highest, counted, and categorized. Categories ranged from low, moderate, and high for level of participation, level of information exposure acceptance, and level of environmental knowledge. Categories ranged from negative, moderate, and positive for environmental attitude. To address the first objective of the research, data were interpreted descriptively using the frequency distribution technique. To address the second objective of the research, analysis of the relationships among variables was conducted using the Spearman Rank correlation method. Spearman Rank correlation analysis measures the strength of associations existing between variables, as presented in Table 1.

Table 1. Spearman Correlation Coefficients

\begin{tabular}{cc}
\hline $\begin{array}{c}\text { Range of Correlation } \\
\text { Coefficients }\end{array}$ & Interpretation \\
$>0,90$ & An almost perfect correlation \\
$0,70-0,89$ & Very high correlation \\
$0,50-0,69$ & High correlation
\end{tabular}


Vita Ruliana, Roekmijati W. Soemantojo, Donna Asteria | ASEAN Journal of Community Engagement | Vol. 3, No. 1, 2019

\begin{tabular}{cc}
\hline $\begin{array}{c}\text { Range of Correlation } \\
\text { Coefficients }\end{array}$ & Interpretation \\
\hline $0,30-0,49$ & Moderate correlation \\
$0,10-0,29$ & Weak correlation \\
$0,01-0,09$ & Very weak correlation \\
0,00 & No correlation \\
\hline
\end{tabular}

Source: (De Vaus, 2002)

The significance of correlations among variables was also examined. The correlation between two variables was considered statistically significant if $p$ value (2-tailed) is lower than 0.05 . Conversely, the correlation between two variables was considered not significant if $\mathrm{p}$ value (2-tailed) is greater than 0.05 . To understand other conditions that may contribute to participation level, answers to questions related to participation level were examined with respondents' profiles by cross-tabulating and reviewing interviews and observations.

\section{Result and Discussion}

\subsection{Level of participation}

The level of participation in waste separation programs in RW 16 as mentioned on Figure 3 varies: A total of $48.8 \%$ of the respondents reported high participation in waste separation activities, $36.3 \%$ reported low level of participation, and 15\% reported moderate level of participation. A high level of participation means respondents separate their household waste 5-7 times a week, a moderate level of participation means respondents separate their household waste 3-4 times a week, and a low level of participation means respondents separate their household waste only 1-2 times a week. The predominant motivation for engaging in waste separation is concern for the environment $(72.6 \%)$. The reason cited most often for not separating waste is inconvenience and time consumption (17.5\%); others report that they do not understand how to separate their waste (7.5\%). 


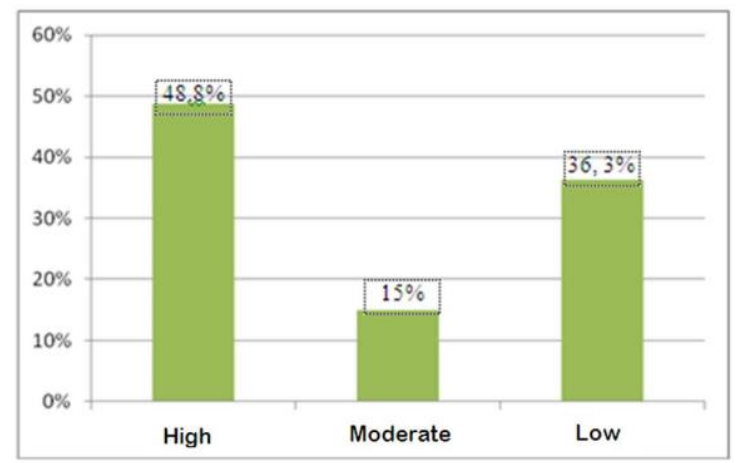

Fg.3 Level of Participation in Waste Separation Activities in RW 16

Source: Results of primary data processing (2017)

\subsection{Level of information exposure acceptance}

Questions on the level of information exposure acceptance probe the respondents' intensity of information acceptance and understanding of the objectives, advantages, and procedures of waste separation. The intensity of information acceptance in RW 16 is low, as shown in Figure 4. As many as $98.8 \%$ of the respondents reported accepting socialization information approximately only 1-2 times a year; the remaining respondents reported accepting socialization information approximately 3-5 times a year. However, interviews from several residents who were actively involved in waste separation reveal that socialization activities related to information dissemination in their neighborhood are not always executed in a formal manner. Instead, the information is provided in the form of persuasive advice conveyed during religious gatherings, such as Eid day, social gatherings, Independence Day and New Year celebrations, and in any other occasion in which a community gathering forms.

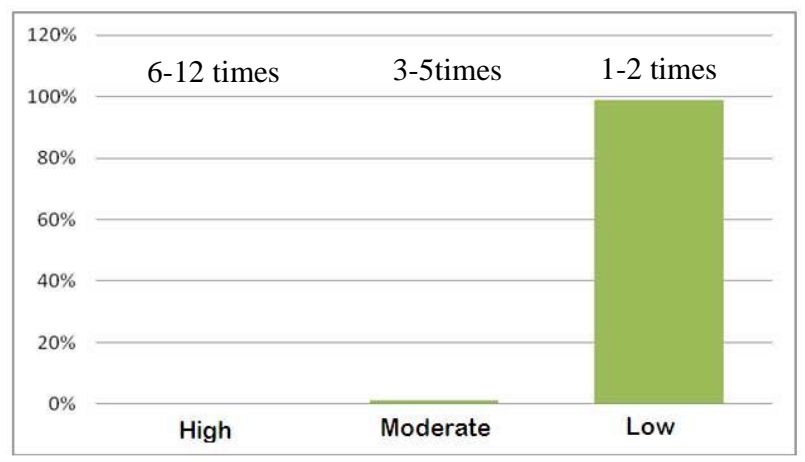

Fg. 4 Intensity of Information Dissemination Exposure in RW 16 Source: Results of primary data processing (2017) 
Vita Ruliana, Roekmijati W. Soemantojo, Donna Asteria | ASEAN Journal of Community Engagement | Vol. 3, No. 1, 2019

\subsection{Correlation between Level of Participation and Level of Comprehension}

The comprehension level of residents as regards the objectives, advantages, and procedures of waste separation is high $(71.3 \%)$ to moderate $(28.8 \%)$. A closer look shows that respondents with a high level of comprehension are mainly those with a high level of participation. By contrast, respondents with a moderate level of comprehension are those with low levels of participation, as seen in Table 2.

Table 2. Correlation between Level of Participation and Level of Comprehension

\begin{tabular}{lcccc}
\hline \multirow{2}{*}{$\begin{array}{c}\text { Level of Comprehension on the } \\
\text { Objectives, Advantages and } \\
\text { Procedures of Waste Separation }\end{array}$} & \multicolumn{3}{c}{ Level of Participation } & \multirow{2}{*}{ Total } \\
\cline { 2 - 4 } & High & Moderate & Low & \\
\hline High & 38 & 11 & 8 & 57 \\
& $(47.5 \%)$ & $(13.8 \%)$ & $(10 \%)$ & $(71.3 \%)$ \\
Moderate & 1 & 1 & 21 & 23 \\
& $(1.3 \%)$ & $(1.3 \%)$ & $(26.3 \%)$ & $(28.8 \%)$ \\
Low & 0 & 0 & 0 & 0 \\
& $(0 \%)$ & $(0 \%)$ & $(0 \%)$ & $(0 \%)$ \\
& 39 & 12 & 29 & 80 \\
& $(48.8 \%)$ & $(15 \%)$ & $(36.3 \%)$ & $(100 \%)$ \\
\hline
\end{tabular}

Source: Results of primary data processing (2017)

Questions on environmental pollution, the environmental and economic benefits of waste separation, and the categories of types of waste, are generally understood by most respondents. Questions on procedures of waste separation and waste management issues in Depok City, such as the critical condition of the city's landfill, are not comprehended by all residents.

\subsection{Level of environmental knowledge}

The level of environmental knowledge among the respondents is generally high (96.3\%) or moderate (3.8\%); none of the respondents report a low level of knowledge, as seen in Table 3. In addition, all respondents with a high level of waste separation participation have high level of environmental knowledge. An interesting finding is that 
Vita Ruliana, Roekmijati W. Soemantojo, Donna Asteria | ASEAN Journal of Community Engagement | Vol. 3, No. 1, 2019

among the $36.3 \%$ of respondents who have low participation in waste separation, most have a high level of environmental knowledge. This result can be explained by assessing the respondents' socio-economic profiles. The educational background of respondents is quite high. In this survey, $68.9 \%$ of the respondent's report having vocational or master's degrees, which also contributes to the high level of environmental knowledge. The economic conditions of the respondents, the majority of which belong to the middle to upper classes, with expenses of Rp 2.6 million to over Rp 10 million per month, also contribute to the high level of environmental knowledge.

Table 3. Correlation Between Level of Participation and Level of Environmental Knowledge

\begin{tabular}{lcccc}
\hline \multirow{2}{*}{$\begin{array}{l}\text { Level of Environmental } \\
\text { Knowledge }\end{array}$} & \multicolumn{3}{c}{ Level of Participation } & \multirow{2}{*}{ Total } \\
\cline { 2 - 4 } & 39 & 12 & 26 & 77 \\
\hline High & $(48.8 \%)$ & $(15 \%)$ & $(32.5 \%)$ & $(96.3 \%)$ \\
\multirow{2}{*}{ Moderate } & 0 & 0 & 3 & 3 \\
& $(0 \%)$ & $(0 \%)$ & $(3.8 \%)$ & $(3.8 \%)$ \\
Low & 0 & 0 & 0 & 0 \\
& $(0 \%)$ & $(0 \%)$ & $(0 \%)$ & $(0 \%)$ \\
& 39 & 12 & 29 & 80 \\
& $(48.8 \%)$ & $(15 \%)$ & $(36.3 \%)$ & $(100 \%)$ \\
\hline
\end{tabular}

Source: Results of primary data processing (2017)

\subsection{Environmental attitude}

Attitude toward the environment is generally positive $(68.8 \%)$ to moderate $(31.3 \%)$, as seen in Table 4. The three levels of participation show nearly equal proportions of attitudes toward the environment, which means this factor cannot solely describe one's participation in waste separation. Therefore, in addition to the results of the descriptive analysis, the strength of the correlation between variables is analyzed to determine which variables have the strongest correlations with participation level in waste separation. 
Vita Ruliana, Roekmijati W. Soemantojo, Donna Asteria | ASEAN Journal of Community Engagement | Vol. 3, No. 1, 2019

Table 4. Correlation between Level of Participation and Environmental Attitude

\begin{tabular}{|c|c|c|c|c|}
\hline \multirow[t]{2}{*}{ Environmental Attitude } & \multicolumn{3}{|c|}{ Level of Participation } & \multirow{2}{*}{ Total } \\
\hline & High & Moderate & Low & \\
\hline \multirow[t]{2}{*}{ Positive } & 28 & 11 & 16 & 55 \\
\hline & $(35 \%)$ & $(13.8 \%)$ & $(20 \%)$ & $(68.8 \%)$ \\
\hline \multirow[t]{2}{*}{ Moderate } & 11 & 1 & 13 & 25 \\
\hline & $(13.8 \%)$ & $(1.3 \%)$ & $(16.3 \%)$ & $(31.3 \%)$ \\
\hline \multirow[t]{2}{*}{ Negative } & 0 & 0 & 0 & 0 \\
\hline & $(0 \%)$ & $(0 \%)$ & $(0 \%)$ & $(0 \%)$ \\
\hline \multirow{2}{*}{ Total } & 39 & 12 & 29 & 80 \\
\hline & $(48.8 \%)$ & $(15 \%)$ & $(36.3 \%)$ & $(100 \%)$ \\
\hline
\end{tabular}

Source: Results of primary data processing (2017)

\subsection{Community's participation determinant}

According to the results of Spearman Rank correlation analysis in Table 5, level of information exposure acceptance, level of environmental knowledge, and attitude toward the environment are significantly correlated with level of participation.

Table 5. Results of Partial Correlation Analysis between Variables

\begin{tabular}{lcccc}
\hline \multirow{2}{*}{ Variable } & \multicolumn{3}{c}{ Level of Participation in Waste Separation } \\
\cline { 2 - 5 } & $\begin{array}{c}\text { Correlation } \\
\text { Coefficient Score }\end{array}$ & Sig. & Decision & $\begin{array}{c}\text { Correlation } \\
\text { Strength }\end{array}$ \\
\hline $\begin{array}{l}\text { Level of Information } \\
\text { Exposure Acceptance }\end{array}$ & 0.706 & 0.000 & Accept Ha & Very high \\
$\begin{array}{l}\text { Level of Environmental } \\
\text { Knowledge }\end{array}$ & 0.515 & 0.000 & Accept Ha & High \\
$\begin{array}{l}\text { Level of Environmental } \\
\text { Attitude }\end{array}$ & 0.228 & 0.042 & Accept Ha & Weak \\
\hline
\end{tabular}

Source: Results of primary data processing (2017)

This finding is confirmed by a significance (2-tailed) value lower than 0.05 for each correlation. Among the correlations of three variables (X) with level of participation (Y), 
16

Vita Ruliana, Roekmijati W. Soemantojo, Donna Asteria | ASEAN Journal of Community Engagement | Vol. 3, No. 1, 2019

that between level of information exposure acceptance and participation was the strongest and most significant correlation found (correlation coefficient, 0.706).

\subsection{Other conditions contributing to participation}

The first condition contributing to level of participation in waste separation involves the respondents' socio-economic profile, such as daily activities, length of residence in the community, and level welfare of the family, as represented by expenditures per month.

Table 6. Cross Tabulation of Level of Participation in Waste Separation

Across Daily Activities

\begin{tabular}{|c|c|c|c|c|}
\hline \multirow[t]{2}{*}{ Daily Activities of Respondents } & \multicolumn{3}{|c|}{ Level of Participation } & \multirow{2}{*}{ Total } \\
\hline & High & Moderate & Low & \\
\hline \multirow{2}{*}{ Working outside home } & 6 & 4 & 10 & 20 \\
\hline & $(7.5 \%)$ & $(5 \%)$ & $(12.5 \%)$ & $(25 \%)$ \\
\hline \multirow{2}{*}{ Retired } & 9 & 2 & 5 & 16 \\
\hline & $(11.3 \%)$ & $(2.5 \%)$ & $(6.3 \%)$ & $(20 \%)$ \\
\hline \multirow{2}{*}{ Housewives } & 24 & 6 & 14 & 44 \\
\hline & $(30 \%)$ & $(7.5 \%)$ & $(17.5 \%)$ & $(55 \%)$ \\
\hline \multirow{2}{*}{ Total } & 39 & 12 & 29 & 80 \\
\hline & $(48.8 \%)$ & $(15 \%)$ & $(36.3 \%)$ & $(100 \%)$ \\
\hline
\end{tabular}

Source: Results of primary data processing (2017)

According to Table 6, respondents who are housewives have a high level of participation in waste separation (30\%); of 20 respondents who work outside the home, only $7.5 \%$ report high levels of participation in waste separation. Table 7 shows that most respondents with a period of stay of over 10 years have a high level of participation in waste separation (37.5\%), while those with a period of stay of less than 3 years have a low level of participation (12.5\%). 
Vita Ruliana, Roekmijati W. Soemantojo, Donna Asteria | ASEAN Journal of Community Engagement | Vol. 3, No. 1, 2019

Table 7. Cross Tabulation of Level of Participation in Waste Separation Across Period of Stay

\begin{tabular}{|c|c|c|c|c|}
\hline \multirow[t]{2}{*}{ Period of Stay of Respondents } & \multicolumn{3}{|c|}{ Level of Participation } & \multirow{2}{*}{ Total } \\
\hline & High & Moderate & Low & \\
\hline \multirow{2}{*}{ Less than 3 years } & 2 & 3 & 10 & 15 \\
\hline & $(2.5 \%)$ & $(3.8 \%)$ & $(12.5 \%)$ & $(18.8 \%)$ \\
\hline \multirow{2}{*}{$3-5$ years 11 months } & 3 & 1 & 1 & 5 \\
\hline & $(3.8 \%)$ & $(1.3 \%)$ & $(1.3 \%)$ & $(6.3 \%)$ \\
\hline \multirow{2}{*}{ 6-10 years } & 4 & 0 & 4 & 8 \\
\hline & $(5 \%)$ & $(0 \%)$ & $(5 \%)$ & $(10 \%)$ \\
\hline \multirow{2}{*}{$\geq 10$ years } & 30 & 8 & 14 & 52 \\
\hline & $(37.5 \%)$ & $(10 \%)$ & $(17.5 \%)$ & $(65 \%)$ \\
\hline \multirow{2}{*}{ Total } & 39 & 12 & 29 & 80 \\
\hline & $(48.8 \%)$ & $(15 \%)$ & $(36.3 \%)$ & $(100 \%)$ \\
\hline
\end{tabular}

Source: Results of primary data processing (2017)

Table 8 compares the percentages of respondents actively involved in waste separation based on monthly expenditures. Among 13 respondents with a monthly expenditure of less than Rp 2.6 million, $5 \%$ are active in sorting waste; by comparison, respondents with a monthly expenditure of more than $\mathrm{Rp} 2.6$ million are more active in waste separation.

Table 8. Cross Tabulation of Level of Participation in Waste Separation Across Monthly Expenditures

\begin{tabular}{lcccc}
\hline \multirow{2}{*}{ Monthly Expenditures } & \multicolumn{3}{c}{ Category of Participation } & \multirow{2}{*}{ Total } \\
\cline { 2 - 4 } & High & Moderate & Low & \\
\hline Rp 1,1 million to Rp 2,5 & 4 & 3 & 6 & 13 \\
million & $(5 \%)$ & $(3.8 \%)$ & $(7.5 \%)$ & $(16.3 \%)$ \\
Rp 2,6 million to Rp 5 & 21 & 3 & 12 & 36 \\
million & $(26.3 \%)$ & $(3.8 \%)$ & $(15 \%)$ & $(45 \%)$ \\
Rp 5,1 million to Rp 10 & 11 & 2 & 9 & 22
\end{tabular}


Vita Ruliana, Roekmijati W. Soemantojo, Donna Asteria | ASEAN Journal of Community Engagement | Vol. 3, No. 1, 2019

\begin{tabular}{lcccc}
\hline \multirow{2}{*}{ Monthly Expenditures } & \multicolumn{3}{c}{ Category of Participation } & \multirow{2}{*}{ Total } \\
\cline { 2 - 4 } & High & Moderate & Low & \\
\hline million & $(13.8 \%)$ & $(2.5 \%)$ & $(11.3 \%)$ & $(27.5 \%)$ \\
More than Rp 10 million & 3 & 4 & 2 & 9 \\
\multicolumn{1}{c}{ Total } & $3.8 \%)$ & $(5 \%)$ & $(2.5 \%)$ & $(11.3 \%)$ \\
& $(48.8 \%)$ & $(15 \%)$ & $(36.3 \%)$ & $(100 \%)$ \\
\hline
\end{tabular}

Source: Results of primary data processing (2017)

The second condition influencing participation is facility availability. The number of respondents with access to small organic waste buckets is $72.5 \%$; the rest of the respondents (27.5\%) have no such access. When correlated with level of participation in waste separation, among 39 respondents with high participation in waste separation, $45 \%$ have small organic waste buckets. Most respondents with low participation do not have small organic waste buckets at home. Field observations also reveal that not all RTs have communal organic-waste bins. Among five cluster samples, only three, that is, RT 01, RT 02, and RT 06, are provided with communal organic waste bins.

This finding is confirmed by the data of daily organic-waste collection released by UPS Gunadarma, which reveal the weights of organic waste in kilograms collected within its areas of service. Out of 13 RTs in RW 16, organic waste is collected only from RT 01, RT 02, and RT 06, as well as from RT 04, RT 07, and RT 10 (samples outside the cluster). The finding is confirmed by direct observations made during the pre-survey by recording the numbers of communal organic-waste bins in every RT during collection by UPS Gunadarma workers in RW 16. Apparently, even if communal organic-waste bins are available in their RT, not all residents are aware of this facility. Only $62.50 \%$ of the respondents know about the organic-waste pick-up service schedule of UPS Gunadarma. This issue seems to stem from the location of the bins, which is often overlooked by the residents, and the lack of socialization of information on waste separation facilities. In an active neighborhood (RT 06), communal organic-waste bins are found in one location that can easily be accessed by residents.

A facility to accommodate non-organic waste is not yet available because the waste bank once owned by the community is no longer in operation. General waste is collected 
Vita Ruliana, Roekmijati W. Soemantojo, Donna Asteria | ASEAN Journal of Community Engagement | Vol. 3, No. 1, 2019

every Monday and Thursday. Such a schedule is designed to collect residual waste to be brought to the landfill but, in fact, all types of waste are also collected. Ultimately, residents themselves manage non-organic waste that is still economically valuable. Used bottles, cans, and household product containers can be given to scavengers or collectors of used goods or simply thrown away along with the residual waste collected on Mondays and Thursdays.

The third condition influencing participation in waste separation is the role of community leaders. Based on interviews with key persons, the head of neighborhood group 01 (RT 01) and an environmental activist of neighborhood group 06 (RT 06) were found to be the main persons behind the sustainability of the waste separation movement in both neighborhood groups. Thus, since the program was introduced in 2014, respondents with a high level of participation in waste separation are found in both neighborhood groups. Further research also reveals that local organizations, such as the Family Welfare Movement, have not been dominant in sustaining waste separation programs.

\subsection{Discussion}

Daily human activities will certainly generate waste. As the population increases, the volume of waste in a city will increase. In the typical traditional municipal solid waste practice, the collected waste is directly dumped into landfills without treatment, such as waste separation, reduce-reuse-recycle (the 3Rs), composting, and waste-to-energy conversion (Permana et al., 2015). Unmanaged pile of solid waste in landfills lead to pollution and degradation of functions in abiotic components of soil, water, and air and will have an impact on biotic component in an ecosystem. Humans are not only members of the social community but also members of the ecological community, as stated by Keraf (2006). As an inseparable member of the ecological community, humans should always attempt to properly manage their waste in order to support the wellbeing of mankind and other living beings. Previous studies acknowledge sustainable waste management with community engagement is seen as an ideal effort in order to overcome the problem of waste management.

This study is focused on community engagement in waste separation, as an integral part of sustainable waste management. Waste is sorted according its material: organic (food, vegetable, and meat scraps, fruits peels), non-organic waste (bottles, cans, used 
Vita Ruliana, Roekmijati W. Soemantojo, Donna Asteria | ASEAN Journal of Community Engagement | Vol. 3, No. 1, 2019

cardboards, food packaging, and plastic bags), and residual waste that cannot be reused or recycled (used diapers, used sanitary napkins, and other containing hazardous and toxic materials). Waste separation at source enhances recycling and composting activity and is expected to reduce the amount of waste transported to landfills. The objective of waste separation in this study is to overcome the crisis of overcapacity of a landfill in the city of Depok. Waste separation is in line with the hierarchy of sustainable waste management presented by Siebel, et al. (2013), which emphasizes on efforts to prevent, minimize, and recycle waste to produce as minimum amount of waste as possible and to leave only residues to be returned to the natural environment. Waste separation enhances recycling and thus further prevents degradation of the quality of environment today and in the future.

Community engagement in waste separation is an example of human consciousness towards its role as a member of ecological community. It is a form of responsible, sustainable, and harmonious interaction between humans and abiotic and other biotic components in the ecological community by returning substances of used resources in a way that is harmless to the natural environment; soil, water, and air. Friction between natural environment, human-built environment, and social environment is minimized. The study of the problems arising from community-based waste management requires approaches from various disciplines. In the first place, water, soil, air contamination, the issue of dispersed waste, illegal dump sites, insufficient collection services are all part of the broader problematic waste management facing many countries cannot be addressed by an environmental friendly technology alone (Siebel et al., 2013). The application of eco-friendly technology can help solve the waste problem, but the endeavor must be part of a sustainable waste management hierarchy rather than an independent approach and end-of-pipe solution. Moreover, the use of technology in landfills only solves the problem at the site, without compromising the issue of dispersed waste and illegal dump sites outside landfills. To deal with the waste problem holistically, approaches from various concepts, such as sustainability, integrated waste management, ecological ethics, law enforcement, social, and local friendly innovation are needed. Therefore, this study seeks to comprehend community participation in waste separation through various contributing factors, such as information dissemination, environmental knowledge and attitude, social and economic factors, and the intrinsic nature of the innovation of waste separation. 


\subsubsection{Correlation Between Level of Participation and Level of Information Exposure} Acceptance

Correlation analysis reveals that level of participation is strongest and most significantly correlated with level of information exposure acceptance (correlation coefficient, 0.706). The importance of delivering information is in line with Von Borgstede \& Andersson (2010) notion that, in addition to technological innovations, the delivery of information on sustainable waste management programs to the community is an important step to raise awareness, educate residents, and encourage community participation. In neighborhood groups where most of the citizens are active in sorting waste, neighborhood officials and fellow residents remind each other to sort their garbage and reprimand those who leave food packets in buckets of organic waste. Residents are also informed about the pick-up schedule of organic waste so that they can walk to the communal bins and dispose of their organic waste into these bins on time. These practices are in accordance with Von Borgstede \& Andersson (2010), who found that implementation of waste separation programs should be accompanied by sufficient information on how and where people can participate.

The fact that dissemination of information, especially information on the activities of the waste bank and the increasingly critical condition of Cipayung Landfill, and socialization activities in all neighborhood groups remains low deserves serious attention. The intensity of information delivery and socialization should be improved, and these activities should be carried out routinely and continuously, as suggested by Ruben \& Stewart (1998) and Wibowo (2010). Repeated calls will form a stimulus to attitude and behavior. The content of the message is also important. Waste-sorting information will be more persuasive if it includes a valid reason explaining why sorting waste is important. Residents must be informed about facts related to the waste problem in their city. Residents must also be introduced to the economic value of waste. The importance of incorporating valid reasons in waste separation socialization activities is in line with the opinions of Arbi (2015) and Young (1988).

\subsubsection{Correlation Between Level of Participation and Level of Environmental Knowledge}

Level of education also contributes to the level of residents' knowledge on the environment, in line with the findings of Sudarmadi, et al. (2001), where the academic 
Vita Ruliana, Roekmijati W. Soemantojo, Donna Asteria | ASEAN Journal of Community Engagement | Vol. 3, No. 1, 2019

group was found to have a higher level of environmental knowledge compared with the general population. Notoatmodjo (2003) argues that knowledge is influenced by the internal factors of individuals, such as their educational background. The results of this study are in line with the findings of Mancl et al. (2003), who showed that communities with low environmental knowledge scores in an Ohio environmental knowledge survey are those with low levels of education. The level of family welfare also contributes to the level of environmental knowledge, consistent with the study results of Mancl et al. (2003), which further revealed that those who scored poor in the Ohio environmental knowledge survey generally have low incomes. The present finding agrees with the opinion of Notoatmodjo (2003), who stated that, in general, low-income groups prioritize spending to meet basic economic needs and consider the need for information, such as through newspapers, television, and internet channels, as nonessential.

Correlation analysis shows that participation in waste separation and level of environmental knowledge have a strong relationship, in accordance with Kaiser et al. (1999), who found that good environmental knowledge promotes eco-friendly behavior. However, a unique case, that is, that most of the respondents who did not sort their waste also had a high level of environmental knowledge, was also found. The researchers argue that, in this study, level of environmental knowledge alone cannot directly predict level of participation in waste separation. Advances in information and technology may increasingly provide the public with insight into various environmental issues, but such knowledge is considered general knowledge and not valuable to everyday life.

\subsubsection{Correlation Between Level of Participation and Attitude Toward the Environment}

Analysis shows that residents who are active or non-active in waste separation exhibit a positive attitude toward the environment. Correlation analysis reveals that participation in waste separation and attitude toward the environment are weakly correlated, with a significance nearly exceeding the required significance (2-tailed) value. These results indicate that a positive attitude toward the environment does not guarantee participation in waste sorting. The correlation between attitude toward the environment and level of participation in waste separation reflects different aspects presented by previous researchers. 
Vita Ruliana, Roekmijati W. Soemantojo, Donna Asteria | ASEAN Journal of Community Engagement | Vol. 3, No. 1, 2019

Some researchers argue that attitude is a factor determining individuals' willingness to change their behavior, as expected in the purpose of message delivery (Von Borgstede \& Andersson, 2010). By contrast, some scholars find that attitude is not always an indicator determining behavior because, in fact, inconsistencies between attitude and behavior often exist (Wright, 2011; Desa et al., 2012), and situational influences or situations may affect the relationship between attitude and behavior (Kaiser et al., 1999). This inconsistency between attitude toward the environment and actual behavior may be related to some residents feeling that waste separation is a hassle, time consuming, or less important than their everyday work and household chores; residents may also dislike walking to the communal organic-waste bins. These reasons are consistent with the opinion of Desa et al. (2012) and Diekmann \& Preisendörfer (1998), who found that the factors of habit, comfort, and lack of understanding of one's roles and responsibilities in protecting the environment are factors inhibiting eco-friendly behavior.

Other conditions that help shape level of participation are daily work, length of stay, welfare level, facility availability, and the role of determining actors. This finding is in line with Setiana (2005) opinion that participation is formed through social interaction between individuals and the community group in which they live. Housewives have more time to interact with each other than a group of workers. Long-time residents usually have closer social interactions than do newcomers. Social interaction between individuals and community members can create a sense of belonging to the community, thereby providing opportunities for individuals to exchange information and discuss expectations and constraints related to waste separation activities. When associated with Setiana (2005) opinion of the complexity of innovation, the technical implementation of a waste separation program determines the desire or unwillingness of residents to participate in this program. Interviews with several respondents reveal that the location of the communal organic-waste bins is either far or hidden; thus, they are often overlooked by residents. The elderly experience difficulties walking to these bins. Only RT 06 has communal organic-waste bins centered and well recognized by its residents. These findings reflect the view of Setiana (2005) that the complexity of innovation can influence the process of adoption of an innovation.

Aquino et al (2008) revealed that one of the factors determining the success of a waste separation program is the near far from residents' houses tend to be used more 
Vita Ruliana, Roekmijati W. Soemantojo, Donna Asteria | ASEAN Journal of Community Engagement | Vol. 3, No. 1, 2019

than those that are not. Active neighborhood groups have attempted to provide door-todoor organic- and non-organic-waste pick up. Another factor contributing to participation is the role of leading or influential actors within the community. The need for these actors is in accordance with the view of Setiana (2005), who found that such actors empower community members to actively participate in a program. Thus, this study finds that, in addition to continuous information dissemination, the availability of facilities to reduce inconvenience while sorting waste, special approaches and incentives provided to lower- to middle-income class residents, and the role of leading actors are important to promote waste separation. Information dissemination can raise public awareness of the role and function of waste separation in protecting the environment. Adequate facilities for both organic and non-organic waste render waste separation easy to accomplish despite the residents' busyness and other limitations. The presence of leading and influential actors can motivate community members to regularly sort their household waste.

\section{Conclusion}

This research presents both theoretical and practical contributions; it contributes to developments in environmental science in urban environments by promoting improved solid waste management not only through environment-friendly technology but also through community involvement. This research reveals that the level of participation in waste separation activities in RW 16 is relatively moderate. The frequency of information dissemination on waste-sorting activities is generally carried out only 1-2 times a year. Although the level of knowledge of the community is high and the general attitude toward the environment is positive, these two factors do not influence participation as strongly as does the level of information exposure acceptance. Therefore, dissemination of information and socialization of waste separation activities should be conducted on a more routine and continuous basis. Overall, the findings of this research are expected to result in improvements to strategies to increase community participation in waste separation programs. Other conditions that may help influence participation are the daily activities of residents, their length of residence in the community, the level of family welfare, the availability of facilities, and the role of leading actors. This work, therefore, suggests thatthe local authority and 
Vita Ruliana, Roekmijati W. Soemantojo, Donna Asteria | ASEAN Journal of Community Engagement | Vol. 3, No. 1, 2019

governmentunderstand the characteristics of target communities to design approaches and campaigns for community-based waste management programs.

\section{Acknowledgements}

This research is carried out because there has never been an attempt to see the development of waste separation implementation that has been running since 2014 in RW 16, Tugu Village, Cimanggis, Depok. This research would not have run well without the help of the parties involved. Therefore, the researchers are grateful to the head of RW 16 Tugu Village Cimanggis Depok, all heads of RT, the residents of RW 16, the officers of UPS Gunadarma, and the Office of Sanitation and the Environment for providing data.

\section{References}

Aquino; Ann, Peachie; Delina; Laurence; Fernandez; Charlemagne; Baguio; Armando, J. (2008). Mobilizing public support for a sustainable solid waste separation: The case study of Santo Tomas municipality, Philippines.

Arbi, A. (2015). Governmental communication strategies in socializing waste management. International Journal of Social Science and Humanity, 6(8), 643-652. https://doi.org/10.7763/ijssh.2016.v6.726

Asteria, D. (2012). Klasifikasi Literasi Lingkungan (Environmental Literacy) pada Perempuan di Tipologi Wilayah Perkotaan. Universitas Indonesia.

De Vaus, D. A. (2002). Survey in Social Research. In New South Wales: Allen \& Unwin.

Desa, A., Abd Kadir, N. B., \& Yusooff, F. (2012). Environmental Awareness and Education: A Key Approach to Solid Waste Management (SWM) - A Case Study of a University in Malaysia. Waste Management - An Integrated Vision. https://doi.org/10.5772/48169

Diekmann, A., \& Preisendörfer, P. (1998). Environmental behavior: Discrepancies between aspirations and reality. Rationality and Society, 10(1), 79-102. https://doi.org/10.1177/104346398010001004

Erlinna, A. (2012). Pengaruh Keberadaan TPA Cipayung Depok terhadap Kualitas Sumber Air Bersih di Wilayah Permukiman Sekitarnya (Dengan Parameter Besi dan Mangan). Universitas Indonesia. 
Vita Ruliana, Roekmijati W. Soemantojo, Donna Asteria | ASEAN Journal of Community Engagement | Vol. 3, No. 1, 2019

Fagariba, C., \& Song, S. (2017). Assessment of impediments and factors affecting waste management: A case of Accra Metropolis. Academia Journal of Environmental Science, 4(8), 144-162. https://doi.org/10.15413/ajes.2016.0125

Handono, M. (2010). Model Pengelolaan Tempat Pemrosesan Akhir (TPA) Sampah Secara Berkelanjutan di TPA Cipayung Kota Depok-Jawa Barat [Tesis]. https://doi.org/http://dx.doi.org/10.1533/9780857094940.305

Kaiser, F., Fuhrer, U., \& Wolfging, S. (1999). Environmental attitude and ecological behaviour. Journal of Environmental Psychology. https://doi.org/10.1080/00377990903493853

Keraf, S. (2006). Etika Lingkungan. Jakarta: Penerbit Buku Kompas.

Mancl, K. M., Carr, K., \& Morrone, M. (2003). Profile of Ohio adults with low environmental literacy. Ohio Journal of Science, 103(3), 38-41.

Notoatmodjo, S. (2003). Pendidikan dan perilaku kesehatan. Jakarta: Rineka Cipta.

O'Brien, S. R. M. (Iowa S. U. (2007). Indications of environmental literacy: using a new survey instrument to measure awareness, knowledge, and attitudes of universityaged students. Retrospective Theses and Dissertations, 113.

Office of Sanitation and Environment Depok City. (2015). Pemutakhiran Strategi Sanitasi Kota Depok.

Ogawa, H. (1996). Sustainable Solid Waste Management in Developing Country. 7th ISWA International Congress and Exhibition, Parallel Session 7, Yokohama.

Permana, A. S., Towolioe, S., Aziz, N. A., \& Ho, C. S. (2015). Sustainable solid waste management practices and perceived cleanliness in a low income city. Habitat International, 49, 197-205. https://doi.org/10.1016/j.habitatint.2015.05.028

Regional Planning Agency Depok City. (2008). Penyusunan Rencana Induk Persampahan Kota Depok Tahun 2008-2018.

Ruben, B. D., \& Stewart, L. P. (1998). Communication and human behavior. Boston: Allyn \& Bacon.

Setiana, L. (2005). Teknik penyuluhan \& pemberdayaan masyarakat. Bogor: Ghalia Indonesia.

Siebel; Maarten, Alexander; Rotter, Vera Susanne; Nabende, Agnes; Gupta, J. (2013). Clean development mechanism: a way to sustainable waste management in developing countries? Journal of Springer Vienna, 65(1), 42-46. 
Vita Ruliana, Roekmijati W. Soemantojo, Donna Asteria | ASEAN Journal of Community Engagement | Vol. 3, No. 1, 2019

https://doi.org/10.1007/s00506-012-0052-4

Soerjani, M. (2009). Pendidikan lingkungan sebagai dasar kearifan sikap dan perilaku bagi kelangsungan kehidupan menuju pembangunan berkelanjutan. Jakarta: Institut Pendidikan dan Pengembangan Lingkungan.

Sudarmadi, S., Suzuki, S., Kawada, T., Netti, H., Soemantri, S., \& Tugaswati, T. A. (2001). A survey of perception, knowledge, awareness, and attitude in regard to environmental problems in a sample of two different social groups in Jakarta, Indonesia. Environment, Development and Sustainability, 3, 169-183.

United Nations Environment Program. (2016). Guidelines for Framework Legislation for Integrated Waste Management. Retrieved from http://www.unep.org/Documents.multilingual/Default.asp?DocumentID=78\&Artic leID $=1163$

Von Borgstede, C., \& Andersson, K. (2010). Environmental information: explanatory factors for information behavior. Sustainability, 2(9), 2785-2798. https://doi.org/10.3390/su2092785

Wibowo, A. (2010). Hubungan Intensitas Terpaan Sosialisasi dan Kampanye terhadap Sikap Masyarakat pada Pelaksanaan Pilwalkot Semarang 2010.

Widiastuti, A., Hartono, D. M., Moersidik, S. S., \& Gusniani, I. (2018). Characteristics of leachate and their effect on shallow groundwater quality (case study: TPA Cipayung, Depok). IOP Conference Series: Earth and Environmental Science, 120(1). https://doi.org/10.1088/1755-1315/120/1/012003

Wright, Y. L. (2011). Relating recycling: Demographics, attitudes, knowledge and recycling behavior among UC Berkeley Students. Journal of Spring. Retrieved from http://nature.berkeley.edu/classes/es196/projects/2011final/WrightY_2011.pdf

Young, R. De. (1988). Exploring the difference between recyclers and non-recyclers: The role of information. Journal of Environmental Systems, 18(4), 341-351. 